\title{
Evaluation of the 8th Grade Cyprus Turkish History Course Book for Compliance with Visual Design Principles
}

\author{
Zeynettin Akkoyun ${ }^{1 *}$, Hasan Samani $^{1}$, Burak Demir ${ }^{1}$, Yücehan Yücesoy ${ }^{1}$
}

${ }^{1}$ Near East University, Nicosia, CYPRUS

*Corresponding Author: zeynettin.akkoyun@gmail.com

Citation: Akkoyun, Z., Samani, H., Demir, B., \& Yücesoy, Y. (2020). Evaluation of the 8th Grade Cyprus Turkish History Course Book for Compliance with Visual Design Principles. Mediterranean Journal of Social $\mathcal{E}$ Behavioral Research, 4(3), 53-58. https://doi.org/10.30935/mjosbr/9602

\begin{abstract}
The purpose of the study is to evaluate the Compliance with the Content and Visual Design Principles of the 8th Grade Cyprus Turkish History Textbook prepared by the TRNC Ministry of National Education and Culture, which is used in the 2019-2020 academic year, with scales prepared in advance by three expert teachers. The sample of the study consists of the 8th grade Cyprus Turkish History Textbook taught in public secondary schools in the 20192020 academic year. In order to collect the data, the relevant literature was examined in accordance with the research, and a study was carried out using the scanning model technique, one of the quantitative research methods. In the analysis of the data, the data obtained with the scales applied by the expert teachers were analyzed and prepared.
\end{abstract}

Keywords: Republic of Turkey, the Turkish Republic of Northern Cyprus, textbook, Cyprus history, visual design, content analysis

Received: 03 Jun. 2020 • Revised: 30 Sep. 2020 • Accepted: 27 Nov. 2020

\section{INTRODUCTION}

From history to the present day, education has been the focus of societies and many definitions related to education have emerged. However, it is not easy to limit it to a single definition because it is in an intricate state. Scientists are doing various studies on education in academic life and many definitions are emerged. Therefore, it is not enough to come up with a single definition for education. From an overview point of view, education and definitions stand out as follows. Training; According to Stein, it is to develop the skills together and harmoniously. According to J. J. Rousseu, it's about raising people by nature. (Sevinç and Kurtaslan 2009). Based on definitions, although education is defined in a different way, it is seen that the common goal is individual and society. As can be seen from the definitions, education is the cornerstone of society. Therefore, education is an important and wide range of activities that should be prepared considering many factors in terms of planning, organizing and implementing for the needs of society.

Every society has a number of social values that it brings from the past to the present. Those values make up the whole culture. People want to build the power that arising from their own culture, a unique lifestyle, an ideological structure. In a society, if every citizen has a special identity/identity, in each society he has his/her own identity/identity. This identity is the culture that society has brought from the past to the present. Culture is the whole of the material and spiritual values that have occurred in society from the past to the present, and then it is transferred to future generations. Human natural and social environmental domination is the whole. This word, which is passed from French to our language, is the identity and existence of society. Each region has its own cultural characteristics, the same or different cultural characteristics as other societies. These elements do not occur in beer, they are accumulations that have come throughout history. When we consider Cyprus as a whole, it is an inevitable fact that it has a rich culture that bears the traces of many civilizations.

It has a unique structure that is the center of attention with both geographical and human structure. Cyprus has a cosmopolitan (consisting of different nations) structure as a society. This indicates that Cyprus has a rich culture. In order for this wealth of society not to disappear, it is imperative to preserve cultural values and pass them on to future generations. That's exactly where education comes in. In this respect, every element that constitutes education and education (educational institutions, plans and programs, philosophy, teaching, materials, etc.) is important. The most important of these items are textbooks.

Textbooks that guide teachers and students are of great importance in our education system. According to the Turkish Language Association; The book is called "a collection of information formed by bringing together printed or handwritten paper leaves with or without hard skin". No matter how much technology develops today, even if 
augmented reality technologies, whether social media or social media, have started to be used in education, $\mathrm{n}$ commonly used material textbooks are textbooks in the educational climate of school administrators and teachers (Demir,2020; Bicen and Demir, 2020; Nacak, Binding, Iron, 2020; Yucesoy, Demir, Baglama, Bastas, Öznacar, 2020). The content of the textbooks is prepared and presented in line with the desired goals to be achieved in the individual. Content prepared in line with these goals is the most effective means of improving the permaneness of behavior. Textbook; it is one of the most important elements of education and training due to the effects it has on individuals, families, society and the nation. (Ataman, 2001).

The regulation of this tool, which is very useful in education and training, requests sufficient care. In other words, textbooks are suitable for the personal structure of individuals, i.e. student-centered, but must be in accordance with the principles of program development in the writing of books. Books should reflect the real problems of society and be aimed at raising individuals who are sensitive to society. At the same time, individuals are required to make samplings from their daily life. Thus, it will be just as easy to stimulate education to social life. The language structure of the textbooks should be written in today's Turkish and the objectives, behaviors and achievements to be achieved should be clearly stated.

In the books, it is important to avoid the concept of "ethnocentric", that is, superior to other cultures, while containing information describing its own culture, lifestyle, tradition, traditions, i.e. the selfstructure of society. The cause-and-conclusion relationship should be clearly emphasized in the history books. (Kucukahmet, 2001). Its history can be thought of as dominoes lined up back-to-back in this context. With the fall of one stone, the other stones fall one after the other. In other words, there are reasons why an event occurs that triggers it. Without a doubt, historical events hold up mirrors and even lead society. The past experiences of people are a source of experience to the present day. Therefore, the cause and conclusion of history issues must be clearly stated. The research was enriched with research and expert opinions on the purpose of contributing to science based on such criteria. The general purpose of this research is to evaluate the 8 th Grade Turkish Cypriot History Textbook in terms of Compliance with the Principles of Content and Visual Design. For this purpose, the following sub-objectives are emphasized;

How is the 8th Grade Turkish Cypriot History Textbook In accordance with the Principles of Visual Design?

- Text Design and Typography Features

- Design of Pictures and Graphics as Visual Elements,

○ Design of Pages,

○ Cover Design

criteria.

\section{METHOD}

\section{Model of Research}

It is aimed to determine the level of the 8th Grade Turkish Cypriot History textbook of the Turkish Republic of Northern Cyprus according to visual design principles and content analysis. In the study, the 8th Grade Turkish Cypriot History textbook of the Turkish
Republic of Northern Cyprus was examined in terms of content and a screening model was used from quantitative method types.

Scan model; It is a research approach aimed at explaining the situation that exists in the past and present in the way it exists (Karasar, 2015). It was done using the "content analysis" technique from the scanning model. When analyzing content, encodings in some parts of the text are defined as a repeatable technique in which they are summarized systemically with smaller content categories. (Büyüköztürk, 2018).

\section{Universe and Sample}

In the study, trnc 8th Grade Turkish Cypriot History textbook was examined in terms of compliance with visual design principles and content analysis. In this research, the 8th Grade Turkish Cypriot History textbook approved by the Board of Education was accepted as the universe. Two different categories were determined in the study of TRNC 8th Grade Turkish Cypriot History textbooks. The first is "Compliance with the Principles of Visual Design", and the second is "Content". There are two types of content in textbooks. They're like, "I'

1) Written content

2) Visual elements and designs.

Visual design elements and appropriateness were given importance in the research because it facilitates the learning of written content and ensures permaneness in learning.

\section{Data Collection Tool:}

The scale used when evaluating books in the research is the "Visual Design Principles" Scale determined by Alpan, (2004). Necessary ethical permissions have been obtained from the scale owner. The scoring of the scales is calculated as 'Yes' option 2 points, 'Partially' option is calculated as 1 point and 'No' option is calculated as 0 points. The data obtained from the data analysis were evaluated by scaling between 1 and 10 .

\section{Data Collection}

All visual elements in the 8th Grade Turkish Cypriot History textbook, which was examined using the "conformity to visual design principles" scale used in the research, were examined and evaluated according to special sub-areas on the scale.

\section{Data Resolution and Interpretation}

The scales used in the 8th Grade Turkish Cypriot History textbook review were determined as 2 points for "Yes", 1 for "Partial" and 0 for "No". In accordance with the visual design principles, a general evaluation of the books and the dimensions of the scale were evaluated separately.

The evaluation of the books on the scale is realized out of 10.10 is the highest score a book can get in the review. According to the results obtained as a result of scaling, the following values created by Alpan (2004) are given the level of conformity:

- Not Appropriate: Values between $0 \leq 2$,

- Partially Appropriate: Values between $2>-\leq 4$,

- ModerateLy Appropriate: Values between $4>-\leq 6$,

- Highly Suitable: Values between $6>-\leq 8$,

- Fully Appropriate: Values between $8>-\leq 10$

scored in the form of a score. 


\section{FINDINGS AND COMMENTS}

8. Class Cyprus and Turkish Cypriot History textbook

Evaluations based on The Scale of Conformity to Visual Design Principles

The Visual "Design Principles Scale" determined by Alpan 2004 consisting of five sections, was used in the evaluation of the 8th Grade Cyprus and Turkish Cypriot History textbook's ability to evaluate its ability to visual design principles. The sections and the scoring obtained as a result of the evaluation of this scale consisting of five sections are given in detail in the tables. The scale consists of a total of 48 items.

Table 1. 8th Grade Cyprus and Cyprus Turkish History Textbook's 1st Expert Scores on The Scale of Conformity to Visual Design Principles

\begin{tabular}{lcc}
\hline Textbook & Publisher & Total Points \\
\hline 8th Grade Cyprus and & & \\
Turkish Cypriot History & Okman Printing & 81 \\
Textbook & \\
\hline
\end{tabular}

Table 2. 1.8 by expert. The Ratio of Total Scores received by the Class Cyprus and Turkish Cypriot History Textbook according to the Scale of Conformity to Visual Design Principles

\begin{tabular}{lcc}
\hline Textbook & Publisher & Total Points \\
\hline 8th Grade Cyprus and & & \\
$\begin{array}{l}\text { Turkish Cypriot History } \\
\text { Textbook }\end{array}$ & Okman Printing & 8.4 \\
\hline
\end{tabular}

Table 3. 1.By expert 8. Distribution of The Scores of the Class Cyprus and Turkish Cypriot History Textbook according to the Scale of Conformity to visual design principles

\begin{tabular}{|c|c|c|c|c|c|}
\hline Publisher & Text Design & $\begin{array}{l}\text { Design of } \\
\text { Visual } \\
\text { Elements }\end{array}$ & $\begin{array}{c}\text { Page } \\
\text { Design }\end{array}$ & $\begin{array}{l}\text { Cover } \\
\text { Design }\end{array}$ & $\begin{array}{c}\text { External } \\
\text { Structure } \\
\text { Properties } \\
\text { for } \\
\text { Production }\end{array}$ \\
\hline 8th Grade & Tipog, I'm & & & & \\
\hline Turkish & not going to & & & & \\
\hline Cypriot & be Oz. :16 & 20 & 13 & 8 & 12 \\
\hline History & Text Ang. :12 & & & & \\
\hline Textbook & Total: 28 & & & & \\
\hline
\end{tabular}

Table 4. 1.By expert 8. Distribution of The Ratios of The Class Cyprus and Turkish Cypriot History Textbook Scores according to the Scale of Conformity to Visual Design Principles

\begin{tabular}{|c|c|c|c|c|c|}
\hline Publisher & Text Design & $\begin{array}{l}\text { Design of } \\
\text { Visual } \\
\text { Elements }\end{array}$ & $\begin{array}{c}\text { Page } \\
\text { Design }\end{array}$ & $\begin{array}{c}\text { Cover } \\
\text { Design }\end{array}$ & $\begin{array}{c}\text { External } \\
\text { Structure } \\
\text { Properties } \\
\text { for } \\
\text { Production } \\
\end{array}$ \\
\hline 8th Grade & Tipog, I'm & & & & \\
\hline Turkish & not going to & & & & \\
\hline Cypriot & be Oz. : 8.9 & 8.3 & 8.1 & 6.6 & 10 \\
\hline History & Text Ang. :8.6 & & & & \\
\hline Textbook & Total: 13.2 & & & & \\
\hline
\end{tabular}

With the data given in Tables 1-4, 8. Class Cyprus and Turkish Cypriot History Textbook has been evaluated for visual design principles. In line with this data, visual design principles are the first stage of the evaluation scale in the Typographic elements section of the Text Design section 8 . The class was found to be fully eligible with a ratio of 8.9 of the Cyprus and Turkish Cypriot History Textbooks. In the 8th Grade Cyprus and Cyprus History Textbook Typographic elements, it was observed that it did not fully comply with the principle of "Effective design of attention-focusing words or words".

In the Text Organizing sub-field of Text Design, the 8th Grade Cyprus and Cyprus History Textbook was found to be fully appropriate with a rate of 8.6. In the Text Organizing sub-field of Text Design, it is seen that it does not fully comply with the principle of "Partially appropriate use of boxes for purpose".

In the design of visual elements section, which is the second part of the Visual Design Principles, the 8th Grade Cyprus History Textbook was found to be fully suitable with a ratio of 8.3 . In the Design of Visual Elements section of the 8th Grade Cyprus History textbook, it has been observed that the "Robust pattern in paintings", "Effective use of highlighting in visual elements", "Coloring of visual elements" do not partially fit the elements.

In the page design section, which is the third part of the Visual Design Principles8. Class Cyprus History Textbook was found to be completely appropriate with a rate of 8.1. In the 8th grade Cyprus History textbook Page Design section, it was determined that "Visual elements do not block the flow of reading" partially do not comply with "Editing the page number as a separate design element".

In the Cover Design section, which is the fourth part of the Visual Design Principles, the 8th Grade Cyprus History Textbook was found to be quite appropriate in proportion to 6.6 in the 8th Grade Cyprus History Textbook Cover Design section, it is seen that it does not partially comply with the article "Being associated with content and page layout", "Paying attention to cover information" and "Preparing the cover aesthetically and albenli”.

The fifth part of the Visual Design Principles, the 8th Grade Cyprus History Textbook, was found to be completely appropriate in the External Building Features for Productionwith a rate of 10.

Table 5. 8th Grade Cyprus and Cyprus Turkish History Textbook's 2nd Expert Scores on The Scale of Compliance with Visual Design Principles

\begin{tabular}{lcc}
\hline Textbook & Publisher & Total Points \\
\hline $\begin{array}{l}\text { 8th Grade Cyprus and } \\
\text { Turkish Cypriot History }\end{array}$ & Okman Printing & 80 \\
Textbook & & \\
\hline
\end{tabular}

Table 6. 2. By expert 8. The Ratio of The Class Cyprus and Turkish Cypriot History Textbook's Total Scores according to the Scale of Conformity to Visual Design Principles

\begin{tabular}{lcc}
\hline Textbook & Publisher & Total Points \\
\hline $\begin{array}{l}\text { 8th Grade Cyprus and } \\
\text { Turkish Cypriot History }\end{array}$ & Okman Printing & 8.3 \\
Textbook & & \\
\hline
\end{tabular}

Table 7. 2.By expert 8. Distribution of The Scores of the Class Cyprus and Turkish Cypriot History Textbook according to the Scale of Conformity to The Principles of Image Design

\begin{tabular}{|c|c|c|c|c|c|}
\hline Publisher & Text Design & $\begin{array}{l}\text { Design of } \\
\text { Visual } \\
\text { Elements }\end{array}$ & $\begin{array}{c}\text { Page } \\
\text { Design }\end{array}$ & $\begin{array}{l}\text { Cover } \\
\text { Design }\end{array}$ & $\begin{array}{c}\text { External } \\
\text { Structure } \\
\text { Properties } \\
\text { for } \\
\text { Production } \\
\end{array}$ \\
\hline 8th Grade & Tipog, I'm & & & & \\
\hline Turkish & not going to & & & & \\
\hline Cypriot & be Oz. :15 & 21 & 12 & 10 & 12 \\
\hline History & Text Ang. :10 & & & & \\
\hline Textbook & Total: 25 & & & & \\
\hline
\end{tabular}


Table 8. 2.By expert 8. Distribution of The Ratios of The Class Cyprus and Turkish Cypriot History Textbook Scores according to the Scale of Conformity to Visual Design Principles

\begin{tabular}{|c|c|c|c|c|c|}
\hline Publisher & Text Design & $\begin{array}{l}\text { Design of } \\
\text { Visual } \\
\text { Elements }\end{array}$ & $\begin{array}{c}\text { Page } \\
\text { Design }\end{array}$ & $\begin{array}{l}\text { Cover } \\
\text { Design }\end{array}$ & $\begin{array}{c}\text { External } \\
\text { Structure } \\
\text { Properties } \\
\quad \text { for } \\
\text { Production }\end{array}$ \\
\hline 8th Grade & Tipog, I'm & & & & \\
\hline Turkish & not going to & & & & \\
\hline Cypriot & be Oz. : 8.3 & 8.7 & 7.5 & 8.3 & 10 \\
\hline History & Text Ang. :7.1 & & & & \\
\hline Textbook & Total: 7.7 & & & & \\
\hline
\end{tabular}

8th Grade Cyprus History Textbook 2. In the evaluation by the expert, it was found to be completely appropriate with a rate of 8.38 . Class Cyprus History textbook is the first dimension of the Visual Design principles scale, and in the Typographic Elements field of text design, it was found to be completely appropriate with 8.38 . In the Class Cyprus History textbook Typographic Elements, it is stated that the line length is readable dimensions and does not partially comply with the principles of "Balanced inter-word spaces", "Paying attention to the integrity of the text on the page".

The first part of the Visual Design Principles, text editing sub-field of text design, was found to be quite suitable with a rate of 7.1 8. It is seen that the class Cyprus History textbook text organizing area does not partially comply with the principles of "Arrangement of the table of contents in a remarkable way", "Partial use of boxes for purpose", "Preparing the relevant title list for each chapter".

Section 8 of the Design of Visual Elements section, the second part of the Visual Design Principles. Class Cyprus History textbook was found to be completely appropriate with a rate of 8.7. In the design section of visual elements, it is seen that the book is partially not suitable for the principles of "Observance of simpliness and simpliability in design", "Effective use of highlighting in visual elements", "Observance of student level in visual elements".

In the Page Design section, which is the third part of the Visual Design Principles, the 8th Grade Cyprus History textbook was found to be quite suitable with a ratio of 7.5, and it was observed that the Cyprus History textbook did not partially comply with the principles of "Ensuring a certain integrity and visual continuity", "Not preventing the reading flow of visual elements", and did not fully comply with the principle of "Effective use of spaces".

In the Cover Design section, which is the fourth part of the Visual Design Principles, the 8th grade Cyprus History textbook was found to be completely appropriate with a rate of 8.3 , and in the Cover Design Section it was determined that it did not partially comply with the principles of "Associated with content and page layout" and "Aesthetic and albenli preparation of the cover".

Chapter 8 of the External Structure Properties for Production, the fifth part of the Visual Design Principles. Class Cyprus History textbook was found to be completely appropriate with 10 proportions.
Table 9. 8th Grade Cyprus and Cyprus Turkish History Textbook's 3rd Expert Scores on The Scale of Compliance with Visual Design Principles

\begin{tabular}{lcc}
\hline Textbook & Publisher & Total Points \\
\hline 8th Grade Cyprus and & & \\
Turkish Cypriot History & Okman Printing & 58 \\
Textbook & & \\
\hline
\end{tabular}

Table 10. 3. By expert 8. The Ratio of The Class Cyprus and Turkish Cypriot History Textbook's Total Scores according to the Scale of Conformity to Visual Design Principles

\begin{tabular}{lcc}
\hline Textbook & Publisher & Total Points \\
\hline 8th Grade Cyprus and & & \\
$\begin{array}{l}\text { Turkish Cypriot History } \\
\text { Textbook }\end{array}$ & Okman Printing & 6.0 \\
\hline
\end{tabular}

Table 11. 3.By expert 8. Distribution of The Scores of the Class Cyprus and Turkish Cypriot History Textbook according to the Scale of Conformity to visual design principles

\begin{tabular}{llcccc}
\hline Publisher & Text Design & $\begin{array}{c}\text { Design of } \\
\text { Visual } \\
\text { Elements }\end{array}$ & $\begin{array}{c}\text { Page } \\
\text { Design }\end{array}$ & $\begin{array}{c}\text { Covernal } \\
\text { Design }\end{array}$ & $\begin{array}{c}\text { Structure } \\
\text { Properties } \\
\text { for } \\
\text { Production }\end{array}$ \\
\hline 8th Grade & $\begin{array}{l}\text { Tipog, I'm } \\
\text { not going to }\end{array}$ & & & & \\
Turkish & be Oz. :6 & 13 & 7 & 7 & 12 \\
Cypriot & Text Ang.:13 & & & & \\
History & Total: 19 & & & & \\
Textbook & & & & & \\
\hline
\end{tabular}

Table 12. 3.By expert 8. Distribution of The Ratios of The Class Cyprus and Turkish Cypriot History Textbook Scores according to the Scale of Conformity to Visual Design Principles

\begin{tabular}{|c|c|c|c|c|c|}
\hline Publisher & Text Design & $\begin{array}{l}\text { Design of } \\
\text { Visual } \\
\text { Elements }\end{array}$ & $\begin{array}{c}\text { Page } \\
\text { Design }\end{array}$ & $\begin{array}{c}\text { Cover } \\
\text { Design }\end{array}$ & $\begin{array}{c}\text { External } \\
\text { Structure } \\
\text { Properties } \\
\text { for } \\
\text { Production }\end{array}$ \\
\hline 8th Grade & Tipog, I'm & & & & \\
\hline Turkish & not going to & & & & \\
\hline Cypriot & be Oz. :3.3 & 5.4 & 4.3 & 5.8 & 10 \\
\hline History & Text Ang. :9.2 & & & & \\
\hline Textbook & Total: 6.2 & & & & \\
\hline
\end{tabular}

If we look at the data obtained in the evaluation of the 8th Grade Cyprus History textbook by the 3rd Expert, the book received a less rate than the rate it received from other experts and was evaluated as quite appropriate with a ratio of 6.0 as a result of the evaluation of the $3 \mathrm{rd}$ expert.

The first dimension of the Visual Design principles scale, Typographic Elements sub-field of Text Design, was found to be partially appropriate with a ratio of 3.3 8th grade Cyprus History textbook 'Effective use of type color or tone value' in Typographic Elements,', "Effective design of attention-focusing words or words", which partially does not comply with the principles of balanced use of horizontal or vertical space between rows", "The line length is readable", "Balanced spaces between words". "It has been determined that the gaps between the letters are balanced and do not fully comply with the principles of "Paying attention to the integrity of the text on the page". 
In the Text Organizing sub-field of Text Design, which is the first part of the Visual Design Principles, the 8th Grade Cyprus History textbook was found to be completely appropriate with a ratio of 9.2, in this field, it is seen that the book partially does not comply with the principle of "Partially appropriate use of boxes for purpose".

In the Design of Visual Elements section, which is the second part of the Visual Design Principles, it is seen that the Cyprus History textbook is moderately appropriate with a ratio of 5.4, in the field of design of visual elements, the book is found to be "Robust pattern in paintings", "Observance of the principle of simpliness and simpliability in design","Visuals effective use of highlighting in elements", "Observance of student level in visual elements", "Observance of the principle of integrity in design", "Proper use of the line", "Compliance with the principle of balance in design", "Proper use of color for purpose". "Proper use of the dimensions of visual elements", "Ensuring a certain integrity and visual continuity" does not partially comply with the principles.

In the Page Design section, which is the third part of the Visual Design Principles, the Cyprus History textbook was found to be moderately appropriate with a ratio of 4.3 , in the book Page Design section, "Ensuring a certain integrity and visual continuity", "Adequate space for visual elements", "Movement in the placement of visual elements "The location of visual elements near the relevant text does not partially comply with the principles of "Inter-arranging two pages", while it has been seen that it does not fully comply with the principles of "Effective use of spaces" and "Ensuring movement in the placement of visual elements".

In the Cover Design section, the Cyprus History textbook was found to be moderately appropriate with a ratio of 5.8 , while it was seen that cyprus history did not partially comply with the principles of "Paying attention to cover information" from the principles in the cover design section of the textbook, "Paying attention to the selection of the type character", "Preparing the cover aesthetically and albenli". The fifth part of the Visual Design Principles, the 8th Grade Cyprus History textbook in External Building Properties for Production, was found to be completely appropriate with 10 proportions.

\section{CONCLUSION AND DISCUSSION}

8. Prepared by the Ministry of National Education and Culture of the Turkish Republic of Northern Cyprus. The class was examined in the light of the visual design principles of the Cyprus History textbook and the results of the evaluations made by experts about the content of the textbook were given and the similarity and differences of the results obtained by the studies in the literature were discussed. As a result of the evaluations made by experts in the visual design principles of the textbook, it is seen that the books are completely appropriate and the expert opinions are appropriate with each other.

Kaptan et al. (2004) stated that the main purpose of typography is to inform the reader audience and the perception of the writing size and characters within the pages. Alpan (2008) also stated that the page color and the tin tones in the text increase readability and make reading an easier process. The experts' 8th Grade Cyprus History textbook shows that there is consensus to give the same statements supporting this in terms of typographic features. According to the data obtained in the study, the opinions of the experts indicated that the elements in the table of contents should be related to the content, and that the elements about the table of contents on the scale should be related to the 8th century. Class Cyprus History stated that the textbook did not partially comply. 8. Class Cyprus History They stated that the textbook was completely appropriate in the evaluation made by experts in the design section of the Visual elements of the Book of History of Cyprus, and that alpan (2004) had a visual effect in his work. In this way, the presentation of the elements increased the imagination of the students and mobilized their motivations against the course, and our study was appropriated by the evaluators from visual design elements as supporting this and received positive reviews from the articles about the status of visual elements in the book. According to the study of Karsl (2013), he stated that the page should be used effectively and free from the elements that will burle the minds of students in page edits in textbooks. 8 in our study. Our experts evaluating the Class Cyprus History textbook stated that it does not partially comply with the "Visual elements do not interfere with the flow of reading", and that the "Editing the page number as a separate design element" does not completely fit.

In his 2019 study, Demir evaluated the Social Studies textbooks of the Turkish Republic of Northern Cyprus and the Republic of Turkey in terms of visual design principles and content, and stated that the books did not fit the item 'Editing the page number as a separate design element' in the Social Studies textbooks of the Turkish Republic of Northern Cyprus. In the same research, it was determined that the cover design contributed positively to the course and that the Social Studies textbooks of the Turkish Republic of Northern Cyprus remained weak in this direction, and as a result of the evaluation of the experts in our study, the cover design was found to be quite appropriate and it was determined by the experts that the "Attention to cover information" and "Aesthetic and albenli preparation of the cover" were partially not complied with.

In this regard, it may be recommended to take the necessary measures in new issues in the Cyprus History textbooks. The external structure characteristics of textbooks for production have been accepted as standards covering the dimensions of the book and all the features necessary for a book to be a book (Kucukahmet, 2003). In our study, 3 experts were 8 . They found the external structure features of the Class Cyprus History textbook for production completely appropriate and gave full score.

\section{REFERENCES}

Alpan, G. (2008). Görsel Okuryazarlık ve Öğretim Teknolojisi. Yüzüncü Yıl Üniversitesi, Eğitim Fakültesi Dergisi, 5(2), 74-102.

Ataman, A. (2001). Özel Gereksinimli Çocuklar ve Özel Eğitime Giriş. Ankara: Gündüz Eğitim ve Yayıncılık.

Bicen, H., \& Demir, B. (2020). A Content Analysis on Articles Using Augmented Reality Technology and Infographic in Education.Postmodern Openings/Deschideri Postmoderne, 11. https://doi.org/10.18662/po/11.1sup1/121

Büyüköztürk, Ş. (2018). Sosyal bilimler için veri analizi el kitabr. Pegem Akademik Yayıncılık. https://doi.org/10.14527/9789756802748

Demir, B. (2020). Evaluation of social studies teaching textbooks. International Journal of Learning and Teaching, 12(1), 1729. https://doi.org/10.18844/ijlt.v12i1.4563 
Gülgün, A. (2004). Ders Kitaplanndaki Grafik Tasarmmn Öğrenci Başansına ve Ders İlişkin Tutumlarnna Etkisi [Doctoral dissertation]. Ankara Üniversitesi.

Karasar, N. (2015). Araştırmalarda rapor hazırlama (19th ed.). Ankara: Nobel Akademik Yayıncılık.

Küçükahmet, L. (2001). Öğretim İlke ve Yöntemleri. Nobel Yayın Dağıtım.

Küçükahmet, L. (2003). Konu alan ders kitabn inceleme kılavuzu. Nobel Yayın Dağıtım.
Nacak, A., Bağlama, B., \& Demir, B. (2020). Teacher Candidate Views on the Use of YouTube for Educational Purposes. Online Journal of Communication and Media Technologies, 10(2), e202003. https://doi.org/10.29333/ojcmt/7827

Sevinç, S., \& Kurtaslan Z. (2009). 'İyilik’ Temalı Okul Şarkılarını Söyleyen Çocukların İyilik Hakkındaki Görüşleri. Ulusal İyilik Sempozyumu, Elazığ.

Yücesoy, Y., Demir, B., Bağlama, B., Baştaş, M., \& Öznacar, B. (2020). Secondary Education Teachers and School Administrators' Views on Positive Organizational Climate. Near East University Online Journal of Education,3(1), 12-21. https://doi.org/10.32955/neuje .$v 3 i 1.188$ 